\title{
Galería de imágenes: "Memoria colectiva en tiempos de genocidios": el arte como forma de narrar en clave de resistencia
}

\author{
María Emilia Nieto* \\ Instituto de Investigaciones en Humanidades y Ciencias Sociales- \\ Universidad Nacional de La Plata-CONICET, Argentina \\ mariaemilianieto@gmail.com
}

En el mes de marzo, a 43 años de la última dictadura argentina, se realizó en el Museo de Arte y Memoria la muestra "Memoria colectiva en tiempos de genocidios". Con la curaduría de Laura Pomerantz*, la misma reunió un conjunto de obras realizadas por seis artistas, en torno a la temática de los genocidios.

A partir de diferentes soportes y materiales, la muestra teje en una trama común las narrativas sobre diferentes crímenes perpetrados sobre los pueblos armenio, tutsi, judío, bosnio y de los diaguitas, lules, sanavirones y tonocotés.

Una pregunta parece resonar de fondo: ¿cómo fue posible? En diferentes escenarios, geografías y tiempos donde se desplegó el horror, el arte irrumpe como un modo de narrar lo que parece inenarrable, como un medio para alojar sentidos, en clave de resistencia.

La primera obra que inaugura la muestra pertenece a Gustavo Larsen, artista platense de larga trayectoria, que explora el concepto de genocidio, acuñado por Rafael Lemkin en 1944. La instalación denominada por el artista como Muestrario del horror (Imagen 1) da inicio al recorrido e invita a explorar el concepto de genocidio, desde las diferentes lenguas, en sus modos de nombrarlo. Sitúa entonces el recorrido de la muestra, en este concepto, invitando a pensar las demás obras en esa clave.

IMAGEN 1

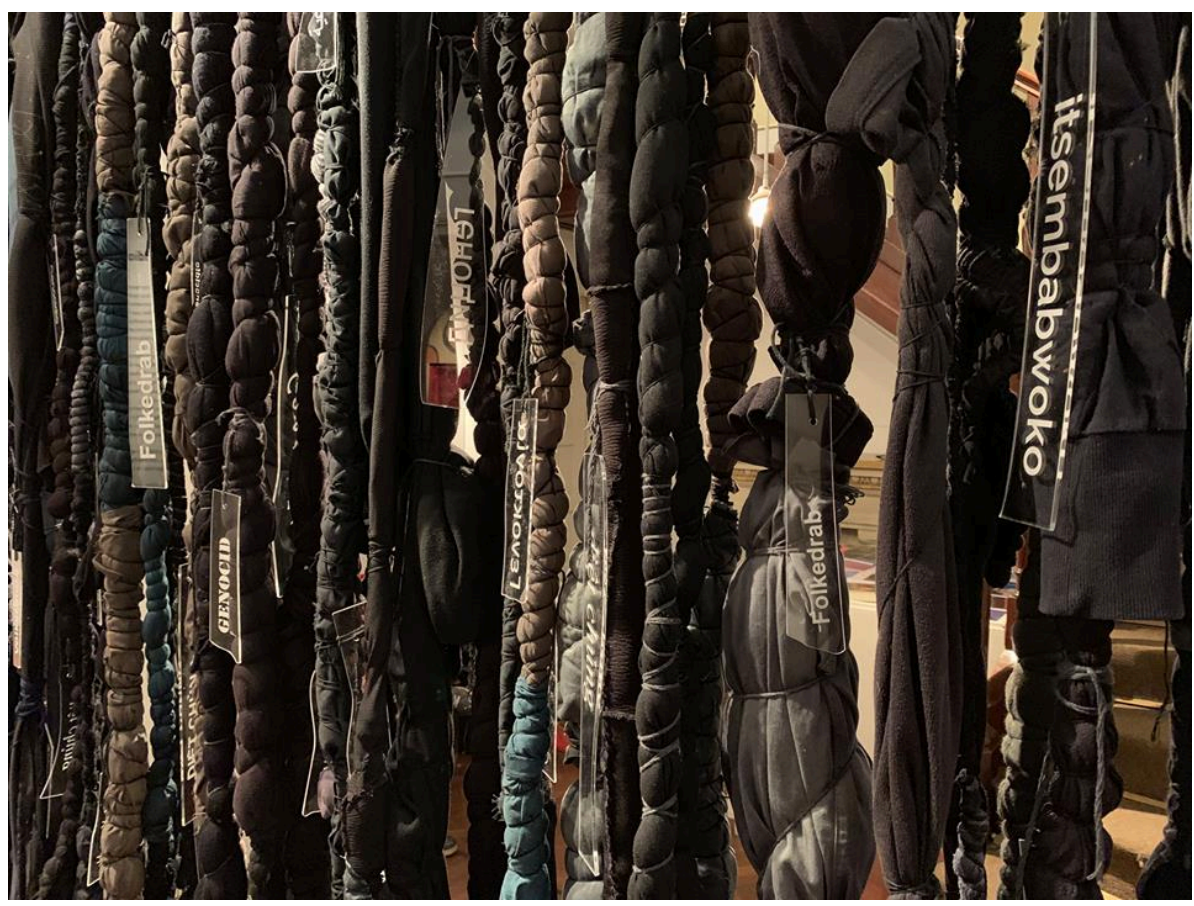


Números de un escriba (Imágenes 2 y 3 ) es la obra realizada por Pedro Roth, artista húngaro sobreviviente del Holocausto, que escapa con su familia del gueto de Budapest. La misma está compuesta por una caja que simula una Sinagoga, y una mesa sobre la que se despliega un extenso pergamino. En él pueden leerse números, que van del 1 a los 6 millones, contabilizando el horror. La escritura del libro sagrado es reemplazada por las cifras, encerrando además un elemento interesante: son escritas por sus hijos y su nieta.

\section{IMAGEN 2}

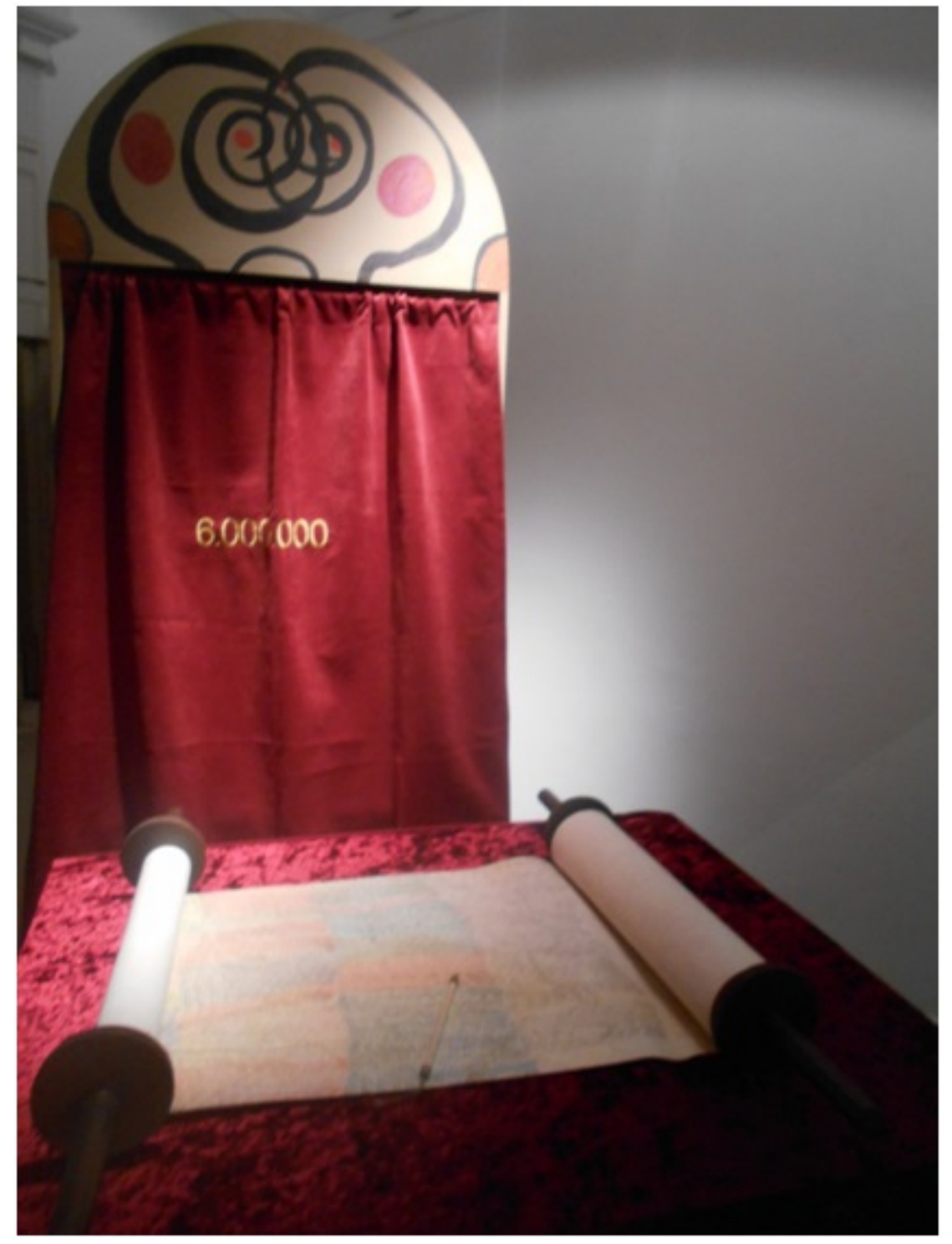


IMAGEN 3

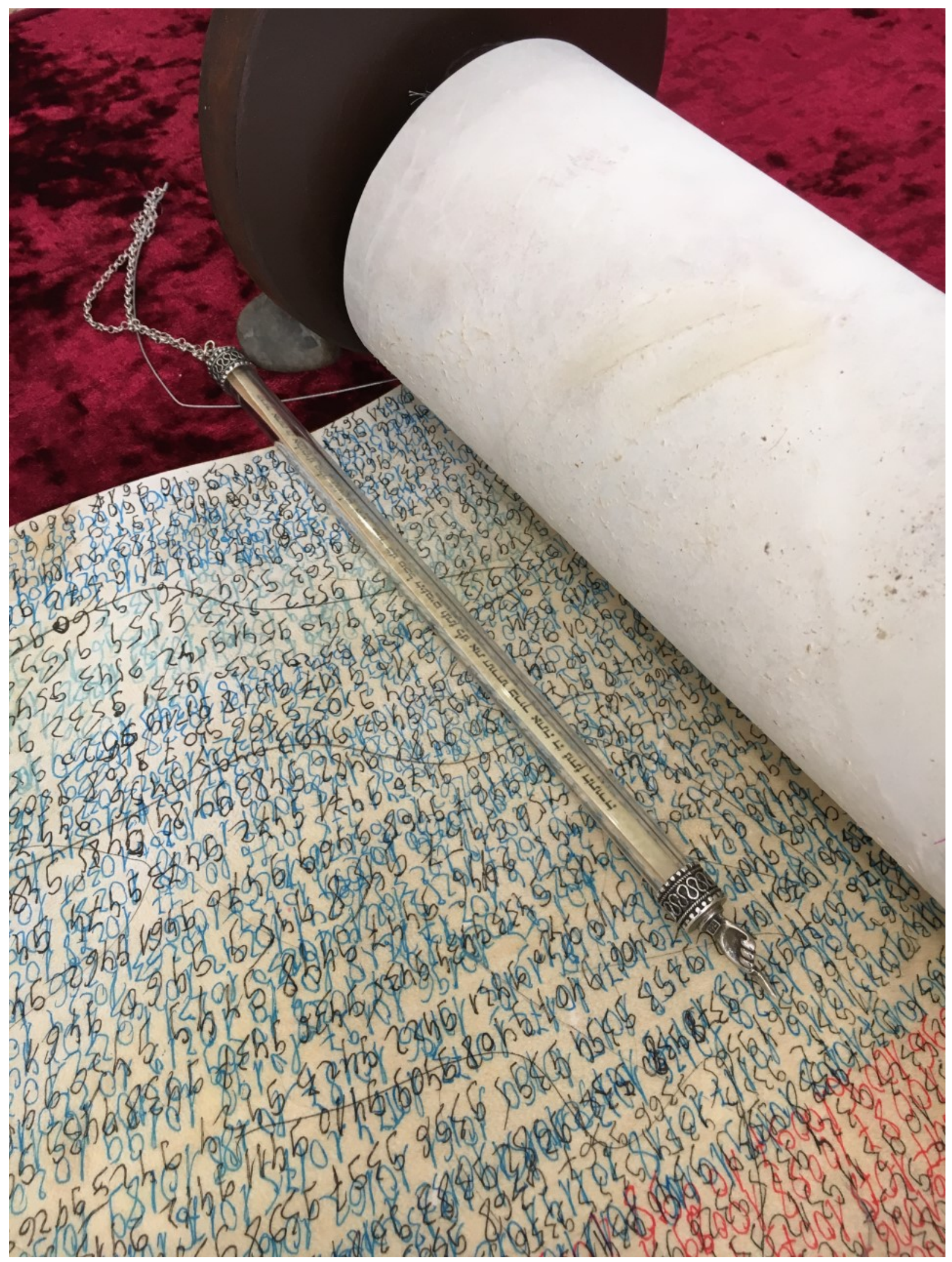

La memoria sobre el genocidio tutsi se entrama en las telas que forman parte de la instalación de Mariela Yeregui denominada Apenas un rostro (Imagen 4). La artista trabaja inspirándose en las típicas telas africanas, realizadas por las mujeres, que contienen simbologías y motivos ancestrales. Pero la mirada atenta sobre 
ellas nos permite ver, como mimetizada, la cara desollada del presidente hutu Juvénal Habyarimana. Yeregui fusiona en las prendas este acontecimiento que inaugura la "temporada de machetes", masacre perpetrada por los hutus contra tutsis. Incorpora a los diseños textiles la foto del rostro del presidente desfigurado, publicada en la Revista Jeune Afrique que guardó durante años, tras recibir por correo dicha publicación. Así este motivo iconográfico propio de las mujeres africanas, se entrama y pasa a ser soporte de la historia de este pueblo masacrado.

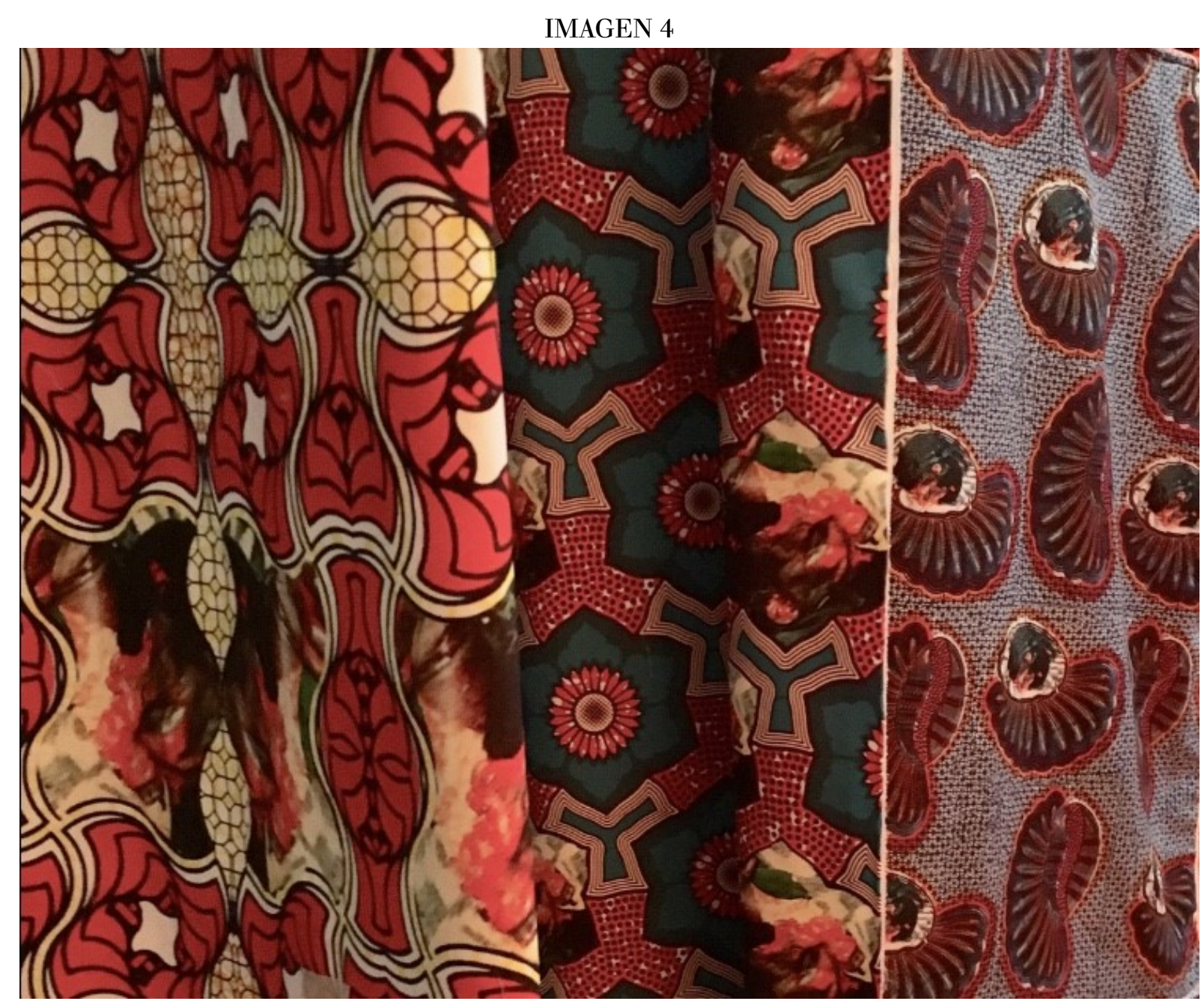

Tríptico de Srebreniça (Imagen 5) es la obra de Enrique Ježik sobre el genocidio bosnio. Compuesta por tres pantallas, en las que se transmiten en simultáneo fragmentos de imágenes sobre acontecimientos claves: la visita de Ratko Mladi 'c -jefe militar responsable de la limpieza étnica- a la zona de seguridad de Srebrenica y el saludo a sus soldados, así como el momento en que es juzgado por el Tribunal Penal Internacional para la ex-Yugoslavia; las filas de víctimas bosnias que son detenidas en autobuses y otras internadas en el bosque, mientras se oyen los disparos que anuncian su destino; el festejo y jolgorio de los cascos azules holandeses de la ONU antes de retirarse del territorio. El montaje de estos fragmentos, que se despliegan en simultáneo, interpelan y desconciertan al espectador/a, mostrando las diferentes escenas de dicho genocidio. 


\section{IMAGEN 5}
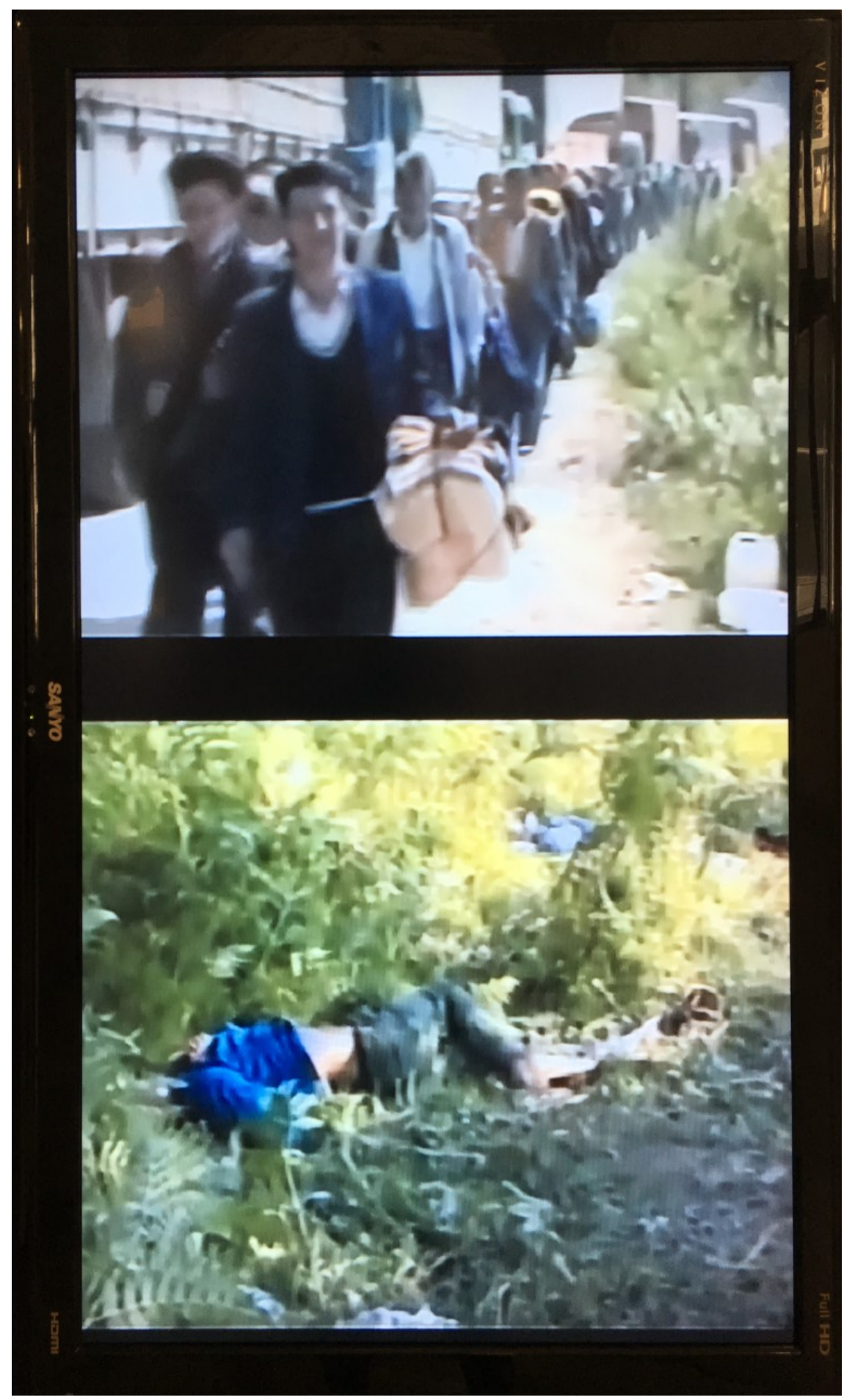

Siguiendo con el recorrido, Ester Nazarian nos introduce en el genocidio armenio, con su obra de gran formato, denominada Cortina de humo (Imágenes 6 y 7). Autora también de la obra in-situ "Pequeñas adversidades", Nazarian es hija y nieta de sobrevivientes armenios, pueblo perseguido y masacrado por el Imperio Otomano entre 1915 y 1918. En esta ocasión la artista interviene el espacio con una gran estructura rígida, forrada con reproducciones de papeles y documentos que pertenecieron a su familia y la acompañaron en la huida. Cúmulos de fotocopias superpuestas que son soporte de la memoria familiar y conforman la textura de esos recuerdos que resisten al olvido. 
IMAGEN 6

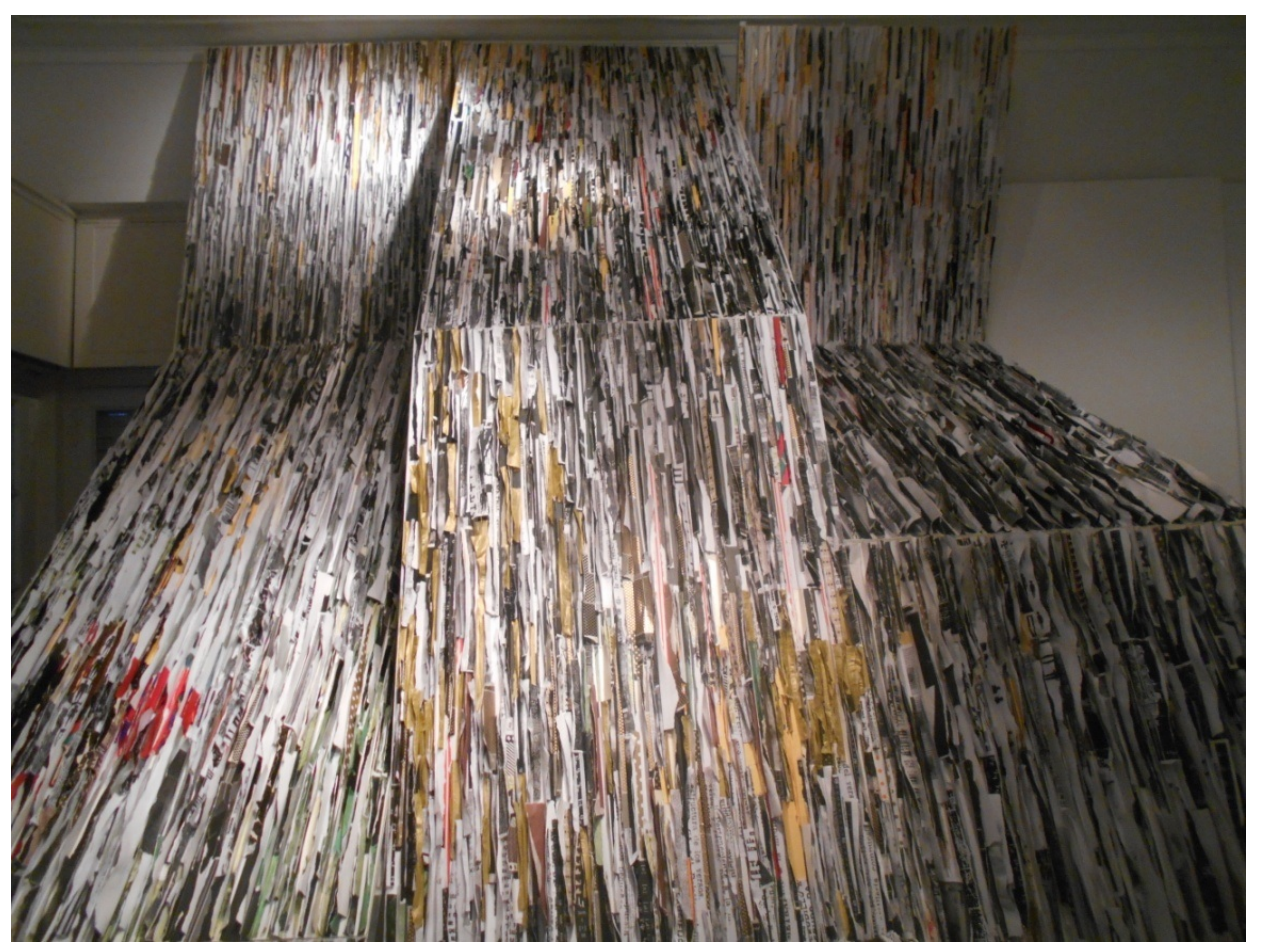

IMAGEN 7

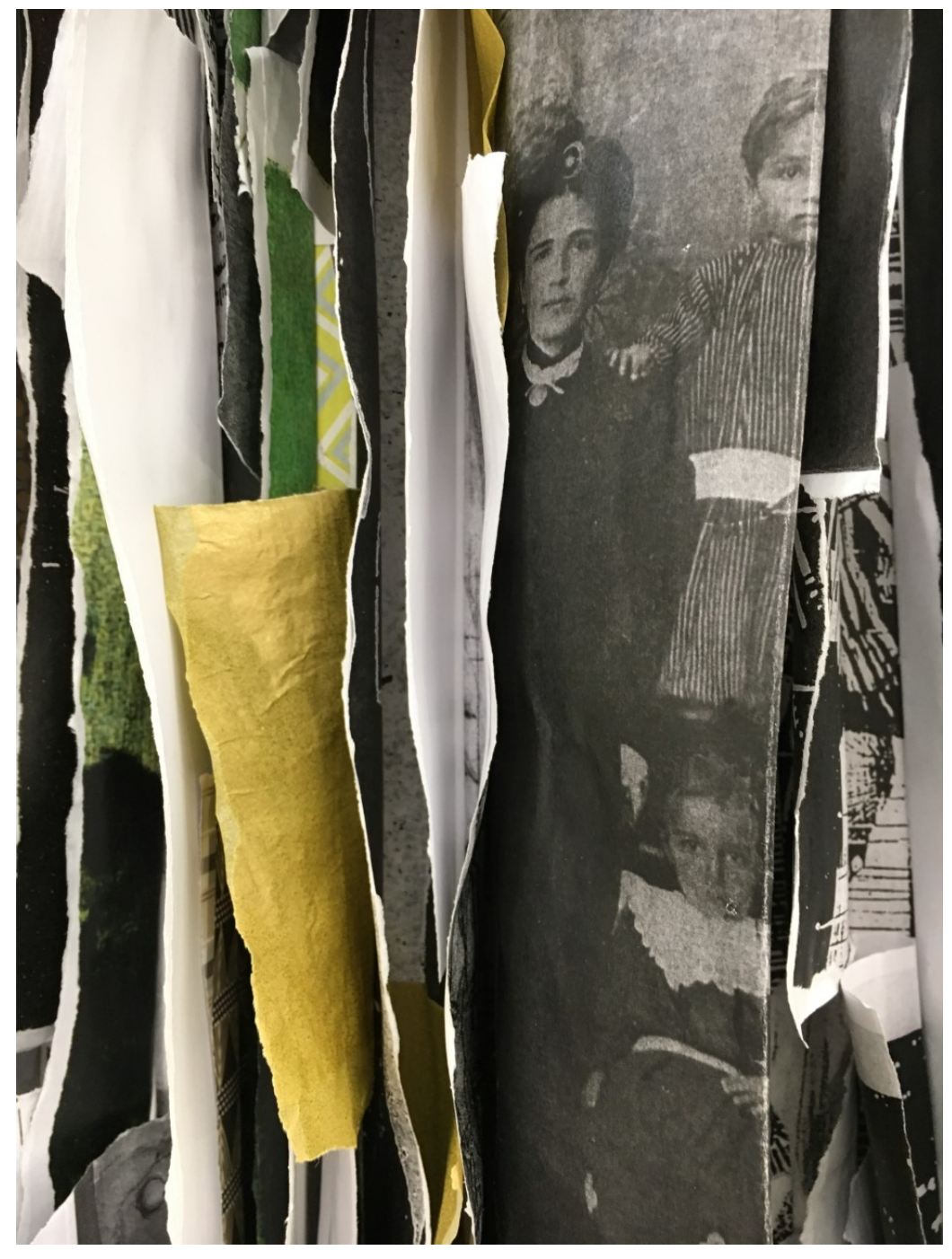


La muestra cierra con la obra de Irene Serra, Huellas, Runasimi, Saqueo, sobre la opresión a los pueblos diaguitas, lules, sanavirones y tonocotés, desde la conquista española, en un derrotero que llega a nuestros días (Imágenes 8 y 9). La artista acumula piezas de cerámica que recrean la muyuna, un hermoso utensilio utilizado para hilar, cuyo nombre deviene del vocablo quechua, muyuy y significa girar. La muyuna aparece en otros dos formatos, en una matriz de ladrillo silicocalcáreo, que puede dejar huella en un papel, si nos animamos a participar y reproducir la imagen. Y por otra parte, en un audio que nombra reiteradas veces la palabra muyuna. El sonido repite circularmente, en diferentes voces y texturas sonoras, aquella palabra que expresa una práctica cultural resistente.

\section{IMAGEN 8}

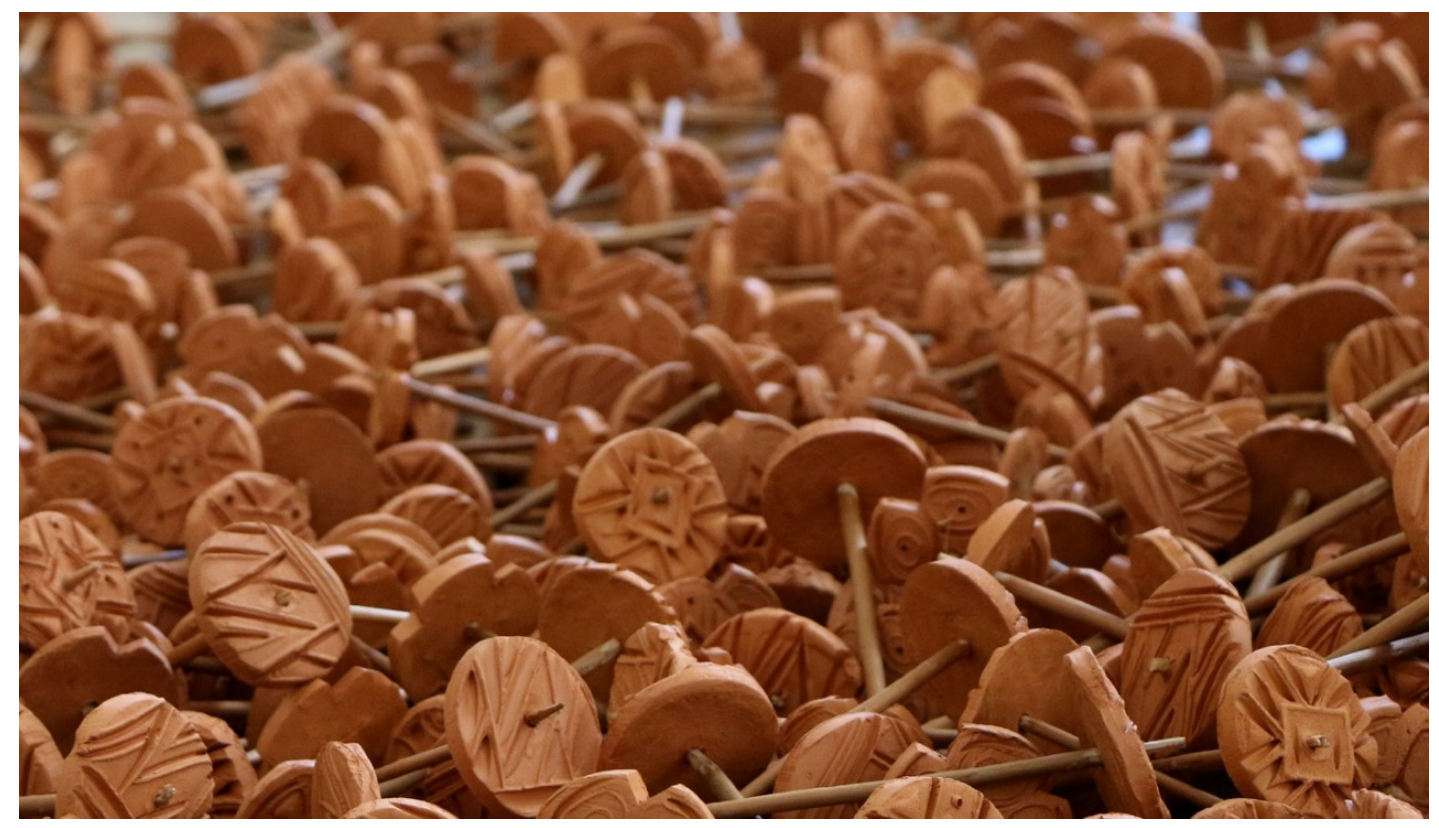

IMAGEN 9

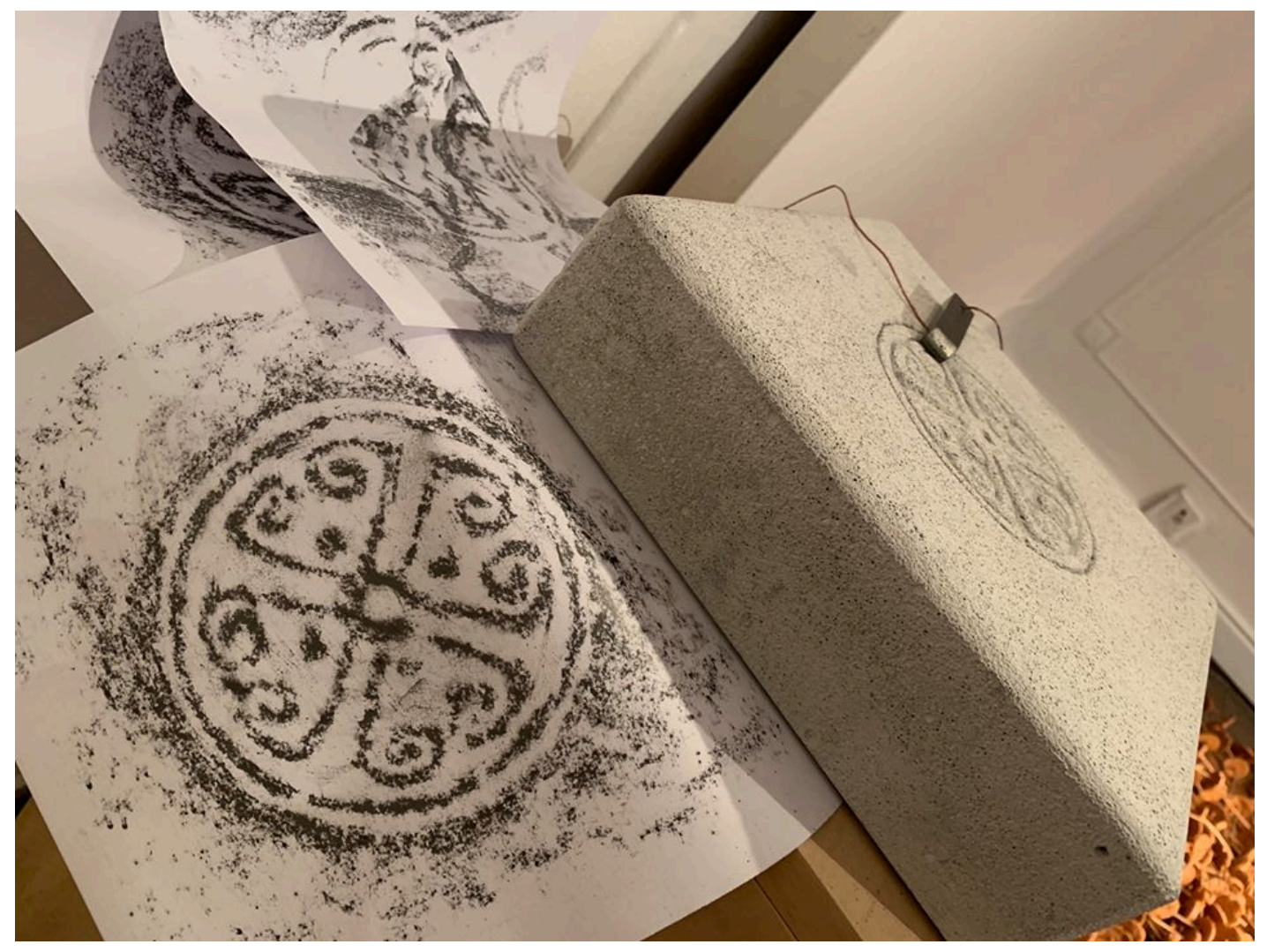


"Memoria colectiva en tiempos de genocidios" nos invita a reflexionar por aquello que liga, une, a estos crímenes. Nos devuelve la pregunta, latente, por la inscripción de la dictadura argentina, en esta trama. Desde un concepto general que remite a una genealogía de la violencia y busca unir bajo su definición a todas estas masacres, el lenguaje del arte vuelve concreto y particular cada historia, de cada pueblo oprimido y perseguido. Volviendo narración lo que parecía imposible y haciendo emerger en esta trama colectiva, las miradas que nos permiten pensar en clave de resistencias. Memorias, gestos y prácticas que dan cuenta de la presencia punzante de lo que se quiso, pero no se pudo eliminar.

\section{Notas DE AUTOR}

* Doctora en Historia de la Arte, por la UNAM (Universidad Nacional Autónoma de México, 2010), en el marco de Filosofía y Letras. Magister en Historia del Arte con mención honorífica (UNAM, 1997). Licenciada en Historia del Arte, con mención honorífica, y en Literatura Hispanoamericana, por la Universidad Hebrea de Jerusalén. Se especializa en Arte Contemporáneo y Genocidio, Arte del Holocausto, Arte Judío, Muralismo Mexicano y Arte Mexicano. Dedicada a la docencia desde 1998 (Universidad Iberoamericana, Casa Lamm, Universidad del Claustro de Sor Juana, Centro Cultural Helénico, en México DF., UNTREF y UBA). A partir del 2012 incursiona en la curaduría independiente. 